\title{
PENDIDIKAN KARAKTER MELALUI KEGIATAN MENDONGENG DI TK ABA KARANGDUWUR DAN TK MASYITHOH PETANAHAN KEBUMEN
}

\author{
Di'amah Fitriyyah ${ }^{1)}$, Darmiyati Zuchdi ${ }^{2)}$ \\ Prodi Linguistik Terapan PPs UNY ${ }^{1)}$,Universitas Negeri Yogyakarta ${ }^{2)}$ \\ amahbintan94@yahoo.com 1), darmiyati@uny.ac.id ${ }^{2)}$
}

\begin{abstract}
Abstrak
Penelitian ini bertujuan untuk mendeskripsikan (1) nilai-nilai karakter dalam dongeng, (2) penyampaian dongeng oleh guru, dan (3) nilai-nilai karakter yang berpengaruh dalam kehidupan sehari-hari siswa. Penelitian kualitatif naturalistik, pengumpulan data dengan observasi, wawancara, dan dokumentasi. Hasil penelitian (1) nilai-nilai karakter yang muncul dalam dongeng yaitu nilai religius, jujur, disiplin, kerja keras, kreatif, mandiri, rasa ingin tahu, gemar membaca, tanggung jawab, toleransi, demokratis, cinta damai, bersahabat/komunikatif, peduli lingkungan, dan peduli sosial. (2) penyampaian dongeng yaitu dengan membacakan dongeng dari buku, bercerita langsung tanpa alat peraga, bercerita dengan alat peraga. Penceritaan dengan menirukan gaya tokoh, menirukan bunyibunyi tokoh, dan menyisipi dongeng dengan nyanyian, diakhiri dengan ayat Quran, Hadis, atau pepatah Arab. (3) Nilai karakter yang berpengaruh pada siswa yaitu nilai religius, jujur, disiplin, kerja keras, mandiri, rasa ingin tahu, tanggung jawab, cinta damai, bersahabat/komunikatif, peduli lingkungan, dan peduli sosial.
\end{abstract}

Kata Kunci: pendidikan karakter, kegiatan mendongeng

\begin{abstract}
This study was aimed to describe (1) character values of fairy tales, (2) the presentation of tales by the teacher, and (3) character values that affect daily life of the students. This was a naturalistic qualitative study. Data collection was done through observation, interviews, and documents. The results of this study show the following. (1) Character education that appears in fairy tales is religious values, honesty, discipline, hard working, creative, independence, curiosity, taking pleasure in reading, responsibility, tolerance, democracy, love of peace, communicativeness, awareness of environment and society. (2) The presentation of the fairy tale is by reading the fairy tales from a book, directly telling stories without props, and telling stories with props. The style of telling story with the sounds of figures, inserting chant in fairy tale, and ending by Al Quran, Hadis, or Arab proverb. (3) Character values that affect in dialy life of student are religious values, honest, discipline, hard working, independence, curiosity, responsibility, love of peace, communicativeness, awareness of environment and society.
\end{abstract}

Keywords: character education, telling fairy tale activities 


\section{PENDAHULUAN}

Kondisi sosial, kultural masyarakat Indonesia akhir-akhir ini memang semakin mengkhawatirkan. Krisis moral melanda negeri ini, kasus kekerasan hampir terjadi di semua kalangan, baik dewasa, remaja, maupun anak-anak. Dalam liputan 6.com tanggal 3 Maret 2012, diberitakan kasus pembunuhan yang dilakukan anak SD di Depok Jawa Barat. Berbagai kasus kriminal lain sering dimuat di surat kabar. Fenomena tersebut memperlihatkan kemorosotan moral.

Pendidikan karakter hadir untuk menjawab dan memperbaiki krisis moral yang terjadi di Indonesia. Terkait dengan pendidikan karakter di TK perlu dilakukan dengan sangat hatihati karena anak usia dini adalah anak yang sedang dalam tahap perkembangan pra-operasional kongkret, sebagaimana dikemukankan oleh Piaget. Sementara nilai-nilai karakter merupakan konsep-konsep yang abstrak, sehingga anak belum bisa secara serta merta menerima apa yang diajarkan oleh guru dengan cepat. Maka guru harus cerdas memilih metode yang akan digunakan. Guru di TK ABA dan TK Masyithoh memilih metode mendongeng untuk mengenalkan pendidikan karakter pada anak.

Ada beberapa manfaat lain yang dapat digali dari kegiatan mendongeng ini. Pertama, anak dapat mengasah daya pikir dan imajinasinya. Anak dapat membentuk visualisasinya sendiri dari cerita yang didengarkan. Ia dapat membayangkan seperti apa tokoh-tokoh maupun situasi yang muncul dari dongeng tersebut. Kedua, cerita atau dongeng merupakan media yang efektif untuk menanamkan berbagai nilai dan etika kepada anak, bahkan untuk menumbuhkan rasa empati. Anak akan belajar dari karakter yang dimuncukan oleh tokoh-tokoh dalam dongeng. ketiga, dongeng dapat menjadi langkah awal untuk menumbuhkan minat baca anak (Noor, 2011, p.50).

Ada suatu ungkapan "Seorang Guru yang tidak bisa bercerita, ibarat orang yang hidup tanpa kepala" (Bimo, 2011, p.10). Guru yang kurang mahir bercerita menyebabkan penceritaan yang disampaikan kurang mengena. Penggambaran anak mungkin bisa keliru ketika penceritaannya tidak tepat. Maka di sinilah peran guru dalam meramu bentuk penyajian dongeng agar menarik bagi anak, dan memanfaatkan media dongeng secara maksimal untuk menanamkan pendidikan karakter bagi anak.
Namun seringkali dalam memanfaatkan metode mendongeng guru-guru di TK ABA dan TK Masyithoh mendapatkan beberapa kendala, kurangnya alat peraga menjadi kendala utama. Beberapa kondisi alat peraga justru dalam keadaan rusak dan sebagian hilang. Dengan minimnya alat peraga yang ada, guru tetap berusaha untuk mendongeng sebagai salah satu media untuk pengajaran akhlak pada siswa.

Di TK ABA banyak terdapat buku-buku dongeng yang diterima dari yayasan, tapi menurut pengakuan guru, buku-buku dongengnya lebih banyak yang berisi hiburan saja dan sedikit berisi tentang pendidikan akhlak. Di sisi lain, buku-buku dongeng yang terdapat di TK Masyithoh banyak yang hilang dan sebagain lagi dalam kondisi rusak. Tanpa buku dongeng guru sedikit kesulitan dalam menyampaikan dongeng karena tidak adanya panduan alur cerita saat mendongeng.

Pada abad ke-14 istilah karakter yang dalam bahasa Perancis "caractere" sudah mulai digunakan, kemudian masuk dalam bahasa Inggris menjadi "character" yang akhirnya menjadi bahasa Indonesia "karakter". Menurut kamus ilmiah popular karakter adalah watak, tabiat, pembawaan, pembiasaan. Senada dengan istilah karakter adalah "personality characteristic yang berarti bakat, kemampuan, sifat, dan sebagainya yang secara konsisten diperagakan oleh seseorang, termasuk pola-pola perilaku, sifat-sifat fisik, dan ciri-ciri kepribadian" (Fitri, 2012, p.20).

Secara terminologi karakter adalah sifat, watak, pembawaan, atau kebiasaan yang mendarah daging yang kemudian menjadi ciri khas seseorang. Menurut Thomas Lickona karakter merupakan sifat alami seseorang dalam merespon situasi secara bermoral (Lickona, 1992, p.51). Sifat alami itu dimanifestasikan dalam tindakan nyata melalui tingkah laku yang baik, jujur, bertanggung jawab, menghormati orang lain dan karakter mulia lainnya. Menurut Kemendiknas (2010), karakter adalah nilai-nilai unik yang terpateri dalam diri dan terejawantahkan dalam perilaku. Dalam Islam karakter dikenal dengan istilah akhlak yaitu sifat yang tertanam dalam jiwa manusia, dan muncul secara spontan tanpa memerlukan pertimbangan atau pemikiran, serta tanpa perlu dorongan dari luar (Ilyas.,2007, p.1), dan berkembang menjadi kebiasaan sedangkan nilainya diletakkan pada ajaran Islam (Izfanna \& Hisyam, 2012, p.77).

Keberhasilan pendidikan karakter ditentukan oleh konsistensi perilaku seseorang yang 
sesuai dengan apa yang diucapkan dan harus didasari atas ilmu pengetahuan dari sumbersumber nilai yang dapat dipertaggungjawabkan. Kesempurnaan pendidikan karakter tercermin dalam perilaku sehari-hari. Pendidikan karakter adalah usaha sengaja untuk menolong orang agar memahami, peduli, dan bertindak atas dasar inti nilai-nilai etis (Jamaluddin, 2013, p.188). Pendidikan karakter juga merupakan suatu sistem pendidikan untuk membangun nilai-nilai karakter pada komunitas sekolah yang melibatkan komponen pengetahuan, kesadaran atau kemauan, dan tindakan menerapkan nilai tersebut, baik ke Tuhan Yang Maha Esa, diri sendiri, manusia lain, lingkungan, atau negara (Siskandar, 2011, p.6).

Puskur dalam rangka lebih memperkuat pelaksanaan pendidikan karakter pada satuan pendidikan telah teridentifikasi 18 nilai yang bersumber dari agama, Pancasila, budaya, dan tujuan pendidikan nasional, yaitu: (1) religius, (2) jujur, (3) toleransi, (4) disiplin, (5) kerja keras, (6) kreatif, (7) mandiri, (8) demokratis, (9) rasa ingin tahu, (10) semangat kebangsaan, (11) cinta tanah air, (12) menghargai prestasi, (13) bersahabat/komunikatif, (14) cinta damai, (15) gemar membaca, (16) peduli lingkungan, (17) peduli sosial, dan (18) tanggung jawab (Pusat Kurikulum. Pengembangan dan Pendidikan Budaya dan Karakter Bangsa: Pedoman Sekolah. 2010, pp.9-10).

Budaya dan pendidikan memberikan pengaruh yang kuat pada perkembangan anak. Di lingkungan pendidikan guru yang luar biasa dapat membimbing dan memberikan pengalaman belajar siswa maka akan membantu mereka bergerak ke tahap kognitif yang lebih tinggi (Santrock, 2011, p.50). Tingkat TK menjadi tempat pertama bagi anak-anak memperoleh pendidikan dan menjadi dasar bagi pendidikan yang lain. Di tempat ini anak lebih cepat mendapat pengaruh dan mudah dibentuk pribadinya. Disinilah pentingnya sekolah sebagai counter untuk menjauhkan anak dari pengaruh lingkungan yang buruk, baik secara jasmani, akal, moral, maupun kepekaan rasanya, sehingga dapat menempatkan pada lingkungan yang baik (Majid, 2008: 4).

Pendidikan karakter yang mulai dibentuk pada diri peserta didik dapat juga terkikis oleh kebiasan buruk yang dilakukan oleh lingkungannya, yaitu pemberian label negatif pada anak. Perilaku labeling pada anak terkadang terjadi tanpa disadari. Labeling merupakan sebuah definisi yang ketika diberikan pada seseorang, maka orang itu akan berproses menjadi seperti label itu. Misalnya anak yang diberi label "bandel atau bodoh" maka lingkungan akan memunculkan kecenderugan pada perlakuan seperti anak "bandel atau bodoh", perlakuan yang secara terus menerus seperti ini akan benar-benar menjadikan anak yang memiliki karakter "bandel atau bodoh" (Wibowo, 2012, p.90). Berdasarkan pemikiran ini hendaklah orang tua dan guru menghidari labeling yang negatif untuk anak.

Dongeng dalam kamus besar bahasa Indonesia berarti cerita yang tidak benar-benar terjadi. Meskipun dongeng hanya cerita fiktif namun mampu mengajak anak untuk berfantasi. Mendengarkan cerita adalah salah satu cara memotivasi anak untuk berpikir tentang karakter (Lickona, 2004, p.201).

Mengingat bahwa tahap perkembangan berpikir anak usia dini adalah tahap operasional kongkret (Hetherington \& Parke, 1986, p.344), sedangkan pendidikan karakter adalah pengetahuan yang abstrak, maka dongeng ini memanfaatkan daya imajinasi anak untuk menjembatani pengetahuan pendidikan karakter yang abstrak. Lewat dongeng inilah pendidikan karakter dapat muncul secara kongkret dalam perilaku tokoh.

Unsur-unsur yang terdapat dalam dongeng juga membantu imajinasi anak dalam memahami alur cerita. Unsur yang terdapat dalam dongeng yaitu: (1) subjek atau tokoh dalam dongeng, (2) waktu dan latar belakang dongeng, (3) tujuan penggambaran suatu keadaan terutama tujuan nilai-nilai positif, (4) dialektika (Suyadi, 2010, p.296).

Daya khayal anak akan mengajak anak berimajinasi untuk memposisikan dirinya seperi tokoh utama, dalam perilaku "ini" dan "itu" yang ditampilkan oleh tokoh utama. Otak anak akan memikirkan, merenungkan, menimbangnimbang yang kemudian diputuskan dalam bentuk ekspresi kejiwaan, sebagimana tokoh utama. Ekspresi-ekspresi itu muncul karena adanya gejolak emosi yang disebabkan oleh alur dongeng tersebut (Suyadi. 2010, p.301). Sejalan dengan konsep Moral Imagination yaitu bahwa orang yang bermoral baik berawal dari imajinasinya yang membayangkan secara intens dan comprehensif bahwa rasa sakit dan kesenangan merupakan bagian dari dirinya (Bohlin. 2005, p.28). Moral Imagination memberikan alasan untuk membayangkan dan mengevalusasi pada tujuan yang layak (Bohlin. 2005, p.29).

Pada saat menyajikan dongeng, hal positif yang terkandung dalam dongeng yang sering 
dilupakan oleh orang adalah mengajarkan anak untuk berekspresi. Kegiatan mendongeng menuntut pendongeng untuk menggerakkan segala ekspresinya, baik melalui suara, gerak tubuh, maupun alat peraga berupa gambar atau boneka. Strategi pembelajaran melalui dongeng menekankan pada seni penyajian pesan-pesan pendidikan dari pendongeng (Kusmiadi dkk, 2008, p.198).

Menurut Moesllchatoen terdapat beberapa macam teknik mendongeng yang dapat dipergunakan yaitu, (1) membaca langsung dari buku, (2) mendongeng menggunakan ilustrasi gambar dari buku, (3) menceritakan dongeng secara langsung, (4) mendongeng dengan menggunakan papan flannel, (5) mendongeng dengan menggunakan media boneka, (6) dramatisasi suatu dongeng, (7) mendongeng sambil memainkan jari-jari tangan (Kusmiadi dkk, 2008, p.200).

Beberapa langkah yang harus dipersiapkan sebelum mendongeng yaitu, (1) pemilihan cerita, (2) persiapan sebelum masuk kelas, (3) setting kelas, dan (4) alat peraga (Majid. 2008, pp.30-33).

Setelah melakukan persiapan, hal lain yang harus diperhatikan guru ketika mendongeng adalah penceritaan, yaitu penyampaian dongeng kepada pendengar atau membacakannya. Pernceritaan meliputi: posisi pendongeng, bahasa, suara, dan visualisasi (Abdul Majid. 2008: 28).

\section{METODE PENELITIAN}

Penelitian ini merupakan penelitian kualitatif. Peneliti mengungkap fenomena pembelajaran di TK yang terkait dengan penanaman nilai-nilai karakter melalui kegiatan mendongeng. Pengambilan data penelitian ini dilaksanakan di TK Aisyiyah Bustanul Athfal Karangduwur dan TK Tarbiyatul Masyithoh Petanahan. Waktu pengambilan data berlangsung sekitar 2 bulan, yaitu antara bulan Desember 2012 sampai Februari 2013.

Subjek penelitian ini adalah guru dan peserta didik di TK Aisyiyah Bustanul Athfal Karangduwur dan TK Tarbiyatul Masyithoh Petanahan. Objek penelitian ini adalah pendidikan karakter melalui kegiatan mendongeng.

Teknik yang digunakan untuk mengumpulkan data dalam penelitian ini adalah observasi, wawancara, dan dokumentasi. Melalui teknik observasi ini peneliti mengamati dengan seksama proses penyampaian dongeng dan penanaman nilai-nilai karakter yang dilakukan guru terhadap peserta didik. Observasi juga dilakukan untuk mengamati pengaruh dongeng dalam keseharian siswa di sekolah. Wawancara dilakukan oleh peneliti untuk memeroleh data tambahan atau untuk penguatan data. Wawancara dilakukan secara mendalam kepada informan yaitu para guru TK dan orang tua peserta didik, sebelum melakukan wawancara peneliti terlebih dahulu membuat pedoman wawancara yaitu berisi daftar pertanyaan yang dijadikan sebagai acuan peneliti untuk memperoleh data. Dokmentasi dilakukan dengan cara melihat dokumentasi berupa pengumpulan data dalam bentuk dokumen buku-buku dongeng yang di pakai oleh guru.

Keabsahan data yang dilakukan oleh peneliti adalah triangulasi berupa triangulasi teknik dan sumber. Triangulasi teknik dimaksudkan untuk crosscheck data yang diperoleh, data yang diperoleh dengan observasi, wawancara, dan dokumentasi akan dibandingkan, dan dicek untuk memperoleh data yang akurat. Triangulasi sumber dimaksudkan untuk crosscheck data dari beberapa sumber yang nantinya akan dibandingkan, dan dicek untuk memperoleh data yang akurat.

Analisis data yang digunakan adalah model analisis Miles And Huberman. Aktivitas dalam analisis data kualitatif yaitu data reduction, data display, dan conclusion drawing/ verification. Reduksi data dilakukan untuk merangkum, memilih hal-hal yang pokok, dicari tema dan polanya. Display data dilakukan dalam uraian singkat, bagan, hubungan antara kategori dan sejenisnya. Langkah berikutnya adalah kesimpulan dan verifikasi.

\section{HASIL PENELITIAN DAN PEMBAHASAN}

Kegiatan mendongeng di TK ABA dan TK Masyithoh tidak terjadwal, guru melihat kondisi siswa ketika akan mendongeng. Saat kondisi siswa tidak terlihat semangat untuk belajar dan malas-malasan maka guru akan mendongeng tapi dengan syarat siswa berjanji mau mendengarkan, jika tidak mau mendengarkan maka guru tidak jadi mendongeng. Siswa juga sering kali meminta guru untuk mendongeng. Kegiatan mendongen sering disampaikan untuk menutup pembelajaran. biasanya dalam seminggu guru mendongeng sebanyak dua atau tiga kali. Dongeng yang sering disampaikan guru adalah dongeng jenis fabel, dongeng biasa yaitu dongeng yang dekat dengan kehidupan seperti dongeng bapak petani, seorang raja, dan do- 
ngeng teladan lainnya, kadang juga tentang kisah Nabi dan orang-orang terdahulu.

Nilai-nilai karakter yang terkandung dalam dongeng yang disampaikan oleh guru di TK ABA dan TK Masyithoh yaitu religius, jujur, disiplin, kerja keras, kreatif, mandiri, rasa ingin tahu, gemar membaca, tanggung jawab, toleran, demokratis, cinta damai, bersahabat/ komunikatif, peduli lingkungan, dan peduli sosial

\section{Religius}

Nilai-nilai religius bersumber dari ajaran agama, terbangunnya pikiran, perkataan dan tindakan berdasarkan ajaran agama. Maka orang yang memilki karakter religius akan mengamalkan ajaran agamanya dalam kehidupan seharihari (Azzet, 2011, p.88).

Pengamalan ajaran agama inilah yang menjadi indikator karakter religius. Pengamalan yang paling mudah dalam kehidupan sehari-hari adalah mengucapkan salam serta berdo'a. tokoh dalam dongeng dengan judul Aturan Baru untuk Ogi, Semut dan Pemburu, dan Labu Ajaib menunjukkan karakter religius dengan mengamalkan ajaran agama yaitu mengucapkan salam dan berdo'a. dongeng ini disampaikan untuk melatih agar anak terbiasa mengucapkan salam serta berdo'a.

\section{Jujur}

Pengetahuan anak tentang perilaku jujur diperoleh melalui dua jalan. Pertama, kemampuan kognitif anak telah menerima bahwa orang yang telah melakukan kesalahan seperti berbohong layak mendapatkan hukuman. Kedua, anak akan memahami bahwa jujur merupakan perbuatan baik atau buruk dari hubungan antara anak dengan orang dewasa di sekitarnya (Sit, 2009, p.1343). anak akan mampu membedakan dampak apa yang diterima dari perbuatan jujur atau berbohong.

Dampak positif dari perbuatan jujur telah dirasakan oleh tokoh dalam dongeng dengan judul Kejujuran dan Raja dan Tahanan. kedua dongeng ini mengajak anak berimajinasi untuk memposisikan dirinya seperti tokoh utama dalam perilaku jujur yang ditampilkan tokoh utama. Otak anak akan memikirkan, merenungkan, menimbang-nimbang yang kemudian diputuskan pada kesimpulan perilaku jujur. Dongeng disampaikan untuk melatih anak berbuat jujur.

\section{Disiplin}

Pada fase pertumbuhan anak usia 4-6 tahun, anak mulai bisa diajak kerja sama serta penurut. Anak sudah dapat menerima pandangan orang lain, bisa menerima otoritas orang tua/ guru, dan menganggap orang dewasa serba tahu. Pada fase ini anak sangat percaya pada orang tua dan guru, sehingga penekanan yang dilakukan oleh orang tua/guru akan pentingnya perilaku baik dan sopan sangat efektif (Wibowo, 2012, p.89).

Penetapan sebuah tata tertib yang berlaku adalah suatu otoritas dari guru yang terwujud dalam sebuah aturan sekolah. Siswa akan dengan mudah menaati aturan sekolah karena anak TK berada pada fase ini. Salah satu aturan sekolah adalah hadir tepat waktu serta menjalankan tata tertib sekolah, ini yang menjadi indikator keberhasilan karakter disiplin siswa.

Kedisiplinan ini telah dilakukan oleh tokoh dalam dongeng dengan judul Menikmati Keterbatasan, Aturan Baru untuk Ogi, dan Hari yang Baik dalam mengikuti aturan dan tata tertib yang berlaku. Lewat dongeng ini siswa mendapatkan gambaran tentang karakter disiplin serta dapat melatih penerapan kedisiplinan di sekolah dan di rumah.

Selain menjalankan tata tertib yang berla$\mathrm{ku}$, menegakkan prinsip reward and punishment juga merupakan indikator keberhasilan karakter disiplin (Fitri, 2012, p.42). Prinsip ini telah ditegakkan oleh tokoh dalam dongeng dengan judul Kejujuran dan Tom Kerdil. Pemberian reward telah dilakukan oleh tokoh dongeng yang telah berjanji akan memberikan hadiah untuk pekerjaan yang baik. Ini adalah sebuah aturan yang dibuatnya sendiri lalu dijalankan. Lewat tokoh-tokoh dongeng yang mempunyai karakter disiplin akan melatih kedisiplinan pada siswa.

\section{Kerja Keras}

Karakter pada hakikatnya merupakan perwujudan fungsi totalitas psikologis yang mencakup seluruh potensi individu manusia (kognitif, afektif, konatif, dan psikomotorik). dan fungsi totalitas sosial kultural dalam konteks interaksi (dalam keluarga, satuan pendidikan, dan masyarakat) dan berlangsung sepanjang hayat. Konteks totalitas ini dapat dikelompokan dalam: Olah Hati (Spiritual and emotional development), Olah Pikir (intellectual development), Olah Raga dan Kinestetik (Physical and kinestetic development), dan Olah Rasa 
dan Karsa (Affective and Creativity development) (Kemendiknas, 2010, p.9).

Dalam fungsi totalitas psikologi kerja keras merupakan ranah psikomotor dan dalam konteks totalitas termasuk dalam kelompok olah raga dan kinestetik. Indikator dari karakter kerja keras adalah berkompetisi secara sehat dan tidak mudah menyerah. Tokoh-tokoh dalam dongeng dengan judul Kejujuran, Tom Kerdil, Semut dan Pemburu, Labu Ajaib, dan Pak Jack Petani yang Rajin memiliki karakter kerja keras karena mampu bersaing secara sehat dan tidak mudah menyerah. Dongeng melatih anak untuk bekerja keras dan tidak mudah menyerah dalam menyelesaikan tugas sekolah.

\section{Kreatif}

Dongeng dalam kamus besar bahasa Indonesia berarti cerita yang tidak benar-benar terjadi. Meskipun dongeng hanya cerita fiktif namun mampu mengajak anak untuk berfantasi. Lewat fantasi inilah anak akan terangsang daya kreatifitasnya, karena salah satu manfaat dongeng bagi anak adalah untuk mengasah daya pikiran dan imajinasi anak. Imajinasi anak yang tertuang dalam bentuk karya yang baru dan berbeda disebut kreatifitas, karena indikator karakter kreatif adalah menciptakan ide-ide baru dan menghargai setiap karya yang berbeda dan unik.

Ide baru yang berbeda dan unik telah diciptakan oleh tokoh-tokon dalam dongeng dengan judul Si Pembuat Roti dan Menikmati Keterbatasan dan Semut dan Pemburu. Tokoh dalam dongeng memiliki karakter kreatif yaitu dengan membuat karya baru yang berbeda dan unik. Maka dongeng ini akan mampu merangsang daya kreatifitas anak.

\section{Mandiri}

Dalam UU No.20 tentang Sisdiknas pasal 1 ayat 14 menyiratkan bahwa pendidikan anak usia dini bertujuan untuk membantu pertumbuhan dan perkembangan jasmani dan rohani anak agar memiliki kesiapan dalam memasuki pendidikan lebih lanjut. Salah satu kesiapan yang diperlukan anak adalah kemandirian. Anak yang mencapai kemandirian akan menunjukkan sikap mampu bekerja secara sendiri, melaksanakan tugas-tugas individu, dan tidak bergantung pada orang lain.

Bekerja secara sendiri serta tidak bergantung pada orang lain telah dilakukan oleh tokohtokoh dalam dongeng dengan judul Tom Kerdil, Si Itik dan Koi, dan Hari yang baik. Tokoh dalam dongeng dapat dikatakan memiliki karakter mandiri karena telah menyelesaikan tugasnya secara sendiri. Dongeng ini akan melatih kemandirian siswa untuk menyelesaikan tugas dan bekerja secara mandiri.

\section{Rasa Ingin Tahu}

Saat mendengarkan dongeng daya khayal anak akan mengajak anak berimajinasi untuk memposisikan dirinya seperi tokoh utama, dalam perilaku "ini" dan "itu" yang ditampilkan oleh tokoh utama. Otak anak akan memikirkan, merenungkan, menimbang-nimbang yang kemudian diputuskan dalam bentuk ekspresi kejiwaan, sebagimana tokoh utama. Ekspresi-ekspresi itu muncul karena adanya gejolak emosi yang disebabkan oleh alur dongeng tersebut (Suyadi. 2010, p.301).

Dengan kata lain dongeng mampu menumbuhkan rasa ingin tahu anak untuk segera mengetahui apa yang akan terjadi dalam cerita selanjutnya. Rasa ingin tahu anak akan terlihat dari sikap dan tindakkan yang selalu berupaya untuk mengetahui lebih mendalam dan luas dari sesuatu yang dipelajarinya, didengar dan dilihat serta suka bertanya.

Suka bertanya yang menjadi indikator karakter rasa ingin tahu ada pada tokoh dalam dongeng dengan judul Menikmati Keterbatasan, Kuni kura-kura, dan Kiki Ingin Berpetualang. karakter tokoh yang telah diciptakan dalam dongeng bertujuan untuk menumbuhkan rasa ingin tahu anak.

\section{Gemar Membaca}

Salah satu manfaat dari dongeng adalah menumbuhkan minat baca anak. Saat anak mulai suka mendengarkan dongeng, anak akan sering minta untuk dibacakan dongeng. Namun saat tidak ada yang membacakannya maka akan tumbuh rasa ingin bisa membaca dongeng sendiri. Gemar membaca akan terlihat dari indikatornya yaitu anak akan menyediakan waktu untuk membaca.

Memanfaatkan waktu luang untuk membaca bahkan sampai menyediakan waktu sendiri untuk membaca terlihat ada pada tokoh dalam dongeng dengan judul Kuni kura-kura. Dengan demikian jelas bahwa tokoh dongeng memiliki karakter gemar membaca yang bertujuan untuk menumbuhkan minat baca anak dan melatih anak menyediakan waktu untuk membaca. 


\section{Tanggung Jawab}

Menurut Thomas Lickona karakter merupakan sifat alami seseorang dalam merespon situasi secara bermoral (Lickona, 1992, p.51). Sifat alami itu dimanifestasikan dalam tindakan nyata melalui tingkah laku yang baik, jujur, bertanggung jawab, menghormati orang lain dan karakter mulia lainnya. Tanggung jawab merupakan bentuk keberanian untuk menerima semua resiko atas segala perbuatan dirinya.

Indikator pencapaian karakter tanggung jawab yaitu mengerjakan tugas dan pekerjaan rumah dengan baik dan bertanggung jawab terhadap setiap perbuatan diri. Sikap inilah yang dimiliki oleh tokoh dalam dongeng dengan judul Si Itik dan Koi, Labu Ajaib, dan Hari yang baik. Tokoh dalam dongeng diciptakan dengan tujuan untuk melatih rasa tanggung jawab anak terhadap tugas atau perbuatan yang telah dilakukannya.

\section{Toleransi}

Indikator dari karakter toleransi adalah memperlakukan orang lain dengan cara yang sama dan tidak membedakan agama, suku, ras, etnis, pendapat, sikap, dan tindakan orang yang berbeda dari dirinya dan menghargai perbedaan yang ada tanpa melecehkan kelompok lain. Sikap tidak membedakan dalam pergaulan ini dimiliki oleh tokoh dalam dongeng dengan judul Hiu dan Remona dan Putri Jelita dan Sejuta Keinginan. Tokoh dalam dongeng ini memperlihatkan bahwa dalam berteman tidak membedakan kedudukan sosial apakah kaya atau miskin. Dongeng ini disampaikan untuk membekali siswa pengetahuan tentang toleransi serta menghargai sesama manusia. Siswa akan melihat bahwa sikap toleransi membuat ia memiliki banyak teman dan disukai banyak teman.

\section{Demokratis}

Diantara misi karya sastra adalah bahwa karya sastra menjadi tempat dimana nilai kemanusian mendapatkan tempat yang sewajarnya dipertahankan dan disebarluaskan (Kinayati, 2006, p.739). Karakter demokratis merupakan ranah sosial yang seharusnya di pertahankan dan disebarluaskan, salah satunya melalui dongeng di lembaga pendidikan usia dini agar karakter ini tertanam sejak usia dini.

Tokoh-tokoh dalam dongeng dengan judul Kisah Acil dan kimang dan Hari yang baik melatih siswa agar menghargai dan menilai sama hak dan kewajiban setiap orang. Inilah yang menjadi indikator tercapainya karakter demokratis. Tokoh dalam dongeng ini telah berusaha mempertahankan sikap demokratis.

\section{Cinta Damai}

Pendidikan karakter juga merupakan suatu proses pendidikan secara holistik yang menghubungkan dimensi moral dengan ranah sosial dalam kehidupan peserta didik sebagai fondasi bagi terbentuknya generasi yang berkualitas yang mampu hidup mandiri dan memiliki prinsip suatu kebenaran yang dapat dipertanggungjawabkan. Oleh karena itu, pendidikan karakter sangat diperlukan dalam mewujudkan peserta didik memiliki prinsip-prinsip kebenaran yang saling menghargai dan kasih sayang antara sesama.

Cinta damai merupakan salah satu karakter untuk mewujudkan prinsip-prinsip kebenaran yang saling menghargai dan kasih sayang antar sesama. Sebagai salah satu karakter dalam ranah sosial, cinta damai memiliki indikator pencapaiannya yaitu cinta damai merupakan sikap, perkataan, dan tindakan yang menyebabkan orang lain merasa senang dan aman atas kehadirannya dan tidak suka berkelahi.

Tokoh-tokoh dalam dongeng dengan judul Bermain dengan Dino, Hiu dan Remona, Saling Memaafkan, dan Putri Jelita dan Sejuta Keinginan menunjukkan karakter cinta damai yang dimiliki yaitu dengan sikapnya yang mudah memaafkan orang lain, senang menolong, dan senang bermain bersama yang pada akhirnya sikap-sikap ini menimbulkan rasa cinta damai dalam pergaulan.

\section{Bersahabat/komunikatif}

Dalam dongeng, pendengar/pembaca akan menemukan berbagai perbuatan tokoh yang dilukiskan pengarang dalam berbagai peristiwa. Melalui alur cerita pengarang memberikan petunjuk, nasihat, pesan akhlak, dan budi pekerti (Kinayati, 2006, p.742). Tokoh dalam dongeng dengan judul Hiu dan Remona, Kuni Kura-kura, dan Putri Jelita dan Sejuta Keinginan telah menciptakan suatu peristiwa lewat dialog. Peristiwa-peristiwa yang muncul telah menggambarkan bahwa si tokoh tidak membeda-bedakan dalam berkomunikasi dan menunjukkan rasa senang berbicara, bergaul, dan bekerja sama dengan orang lain. hal ini merupakan indikator dari karakter bersahabat/komunikatif, jadi secara tidak langsung tokoh dalam dongeng ini berusaha mengajak pendengar/pembaca agar tidak 
membeda-bedakan dalam berkomunikasi dan bersahabat.

\section{Peduli Lingkungan}

Dongeng jenis biasa merupakan dongeng yang mengisahkan cerita yang bermuatan suka dan duka yang dikemas sedemikian rupa sehingga menjadi cerita yang menarik dan bermuatan moral. Manfaat dari dongeng ini biasanya memiliki kisah retorika dalam cerita yang bisa ditemukan pada kehidupan sehari hari. Sebagai contoh rasa saling sayang menyayangi antara sahabat, keluarga dan seluruh lingkungan yang ada. Dalam dongeng ini kecenderungan kemiripan dengan realita yang ada memang lebih besar dari pada dongeng binatang/fabel.

Dongeng jenis biasa ini lebih dekat dengan lingkungan, seperti lingkungan sekolah, keluarga, dan masyarakat. Seperti yang dilakukan oleh tokoh-tokoh dalam dongeng dengan judul Pak Koksi dan Kumbang Koksi, Si Itik dan Koi, dan Labu Ajaib. Tokoh dalam dongeng ini menunjukkan sikap peduli lingkungan dengan pencapaian indikator peduli lingkungan yaitu dengan menjaga lingkungan, membuang sampah pada tempatnya, dan tidak merusak lingkungan. Tokoh-tokoh dalam dongeng ini mengajak pada siswa agar peduli terhadap lingkungan sekitar.

\section{Peduli Sosial}

Karakter peduli sosial seseorang tercermin antara lain dalam perbuatan yang mencerminkan sikap dan suasana kekeluargaan dan kegotongroyongan (kemendiknas, 2010, p.21). Sikap tersebut dapat diketahui melalui indikator pencapaiannya yaitu suka menolong orang lain, melakukan kegiatan bakti sosial, dan suka bersedekah.

Tokoh-tokoh dalam dongeng dengan judul Kejujuran, Bermain dengan Dino, Si Itik dan Koi, Iri Hati, Semut dan Pemburu, Labu Ajaib, dan Pak Jack Petani yang Rajin telah mencerminkan sikap suka menolong orang lain yang sedang kesusahan, dan juga suka bersedekah pada orang yang membutuhkan. Maka dengan jelas karakter tokoh dalam dongeng ini mengajak siswa agar suka menolong dan suka bersedekah yang nantinya menjadi karakter peduli sosial.

Penyajian dongeng dalam dunia pembelajaran merupakan suatu teknik transfer pengetahuan pada siswa. Teknik penyampaian yang dilakukan oleh guru atau pendongeng akan berbeda sesuai dengan keahlian masing-masing. Dongeng dikemas dengan teknik penyajian agar dongeng yang didengar lebih menarik dan lebih mudah diterima oleh pendengar atau siswa. Teknik yang dimaksud disini adalah teknik mendongeng dengan berbagai cara, seperti mendongeng dengan membaca langsung dari buku, mendongeng menggunakan ilustrasi gambar dari buku, menceritakan dongeng secara langsung tanpa alat peraga, dan dramatisasi suatu dongeng.

Mendongeng bukanlah semata-mata untuk menghibur saja atau melucu di depan siswa agar terkekeh-kekeh. Tujuan dari mendongeng adalah memberikan pengetahuan baru bagi siswa. Dongeng juga mampu mengasah daya pikir dan imajinasi siswa, sebagai metode penyampaian moral yang efektif, menumbuhkan minat baca, menjadi suatu jembatan spiritual yang mengarah pada kedekatan emosional antara guru dan siswa, dan memicu daya kreatifitas dan memancing wawasan yang luas bagi guru.

Kemasan penyajian dongeng tidak boleh berlebihan dan keluar dari konteks pendidikan. Penyisipan yang berlebihan akan mengakibatkan kegagalan dalam mencapai tujuan dongeng. Penyisipan dongeng dengan nyanyian, visualisasi tokoh, dan tiruan bunyi memang sangat diperlukan untuk menarik perhatian pendengar, tapi hal ini tidak perlu berlebihan dan mendominasi dalam mendongeng. Teknik ini juga dilakukan oleh guru-guru TK ABA dan TK Masyithoh, namun tidak secara berlebihan. Teknik yang sederhana tanpa melupakan tujuan dari mendongeng. Tahap persiapan sebelum mendogeng adalah guru memilih dongeng yang akan disampaikan, membaca buku dongeng, dan mempersiapkan alat peraga jika dongeng membutuhkan alat peraga. Persiapan ini dilakukan di sekolah saat jam istirahat.

Penyajian dongeng yang dilakukan oleh guru TK ABA dan TK Masyithoh adalah dengan teknik membacakan cerita dari buku, bercerita secara langsung tanpa alat peraga dan dramatisasi dengan menggunakan bahan mainan. Guru juga melakukan dramatisasi dengan menirukan gaya tokoh dalam dongeng, melakukan tiruantiruan bunyi tokoh dongeng. Guru kadang menyisipi dengan nyanyian yang sesuai dengan tema dongeng. Kekhasan yang dilakukan oleh guru dalam mendongeng adalah selalu menyisipi ayat al-Quran ataupun Hadis sebagai penguatan nasihat dalam dongeng. Bahasa yang digunakan dalam menyampaikan dongeng adalah bahasa Indonesia dan bahasa Jawa, bahasa Jawa digunakan untuk lebih memahamkan anak. 
Salah satu usaha yang dilakukan oleh guru-guru TK untuk mananamkan akhlak pada siswa adalah dengan dongeng. Menurut para guru di TK ABA dan TK Masyithoh dongeng sangatlah penting dalam suatu pendidikan akhlak. Melalui dongeng akan mengundang pembaca atau pendengar untuk mengikuti peristiwanya dan merenungkan maknanya. Selanjutnya makna-makna itu akan menimbulkan kesan dalam hati. Siswa akan cenderung lebih bisa menangkap isi pesan yang disampaikan dengan kasih sayang dan lembut. Dongeng menjadi salah satu cara penyampaian nasihat yang disukai siswa.

Dongeng ini memang bukan satu-satunya yang dilakukan guru untuk menanamkan perilaku baik pada anak, guru juga melakukan dengan metode pembiasaan dan keteladanan. Namun guru mengakui bahwa metode mendongeng adalah metode pembelajaran yang baik serta bertujuan untuk mengenalkan anak tentang pengetahuan baik dan buruk, karena dalam mendongeng selalu dibarengi dengan pemberian nasihat. Akses bagi guru untuk memberikan materi pelajaran akhlak adalah lewat dongeng. Jadi dalam metode pembiasaan dan keteladanan adalah di ranah praktisnya dan metode dongeng adalah di ranah teoretisnya atau pegetahuannya, menurut guru perilaku siswa merupakan cerminan dari pengetahuan yang dimilikinya. Karena itu pembinaan melalui dongeng sangatlah penting. Nilai karakter yang muncul dalam keseharian siswa di sekolah yaitu nilai religius, jujur, disiplin, kerja keras, mandiri, rasa ingin tahu, tanggung jawab, demokratis, cinta damai, bersahabat/komunikatif, peduli lingkungan, dan peduli sosial.

\section{SIMPULAN DAN SARAN}

Nilai-nilai karakter yang terkandung dalam dongeng yang disampaikan oleh guru di TK ABA dan TK Masyithoh yaitu religius, jujur, disiplin, kerja keras, kreatif, mandiri, rasa ingin tahu, gemar membaca, tanggung jawab, toleran, demokratis, cinta damai, bersahabat/komunikatif, peduli lingkungan, dan peduli sosial.

Wujud penyampaian dongeng yang dilakukan oleh guru TK ABA dan TK Masyithoh yaitu dengan teknik membacakan cerita dari buku, bercerita menggunakan ilustrasi gambar, bercerita secara langsung tanpa alat peraga, dan bercerita dengan alat peraga. Penceritaan yang dilakukan oleh guru yaitu menirukan gaya tokoh dalam dongeng, menirukan tiruan-tiruan bunyi tokoh dalam dongeng, terkadang guru juga menyisipi dongeng dengan nyanyian. Penyam- paian hikmah atau nasihat yaitu dengan menyisipi ayat Quran atau Hadis maupun pepatah Arab.

Nilai-nilai karakter dongeng yang berpengaruh dalam diri siswa terlihat dalam keseharian siswa di TK ABA dan TK Masyithoh. Karakter siswa yang teraktualisasi yaitu nilai religius, jujur, disiplin, kerja keras, mandiri, rasa ingin tahu, tanggung jawab, demokratis, cinta damai, bersahabat/komunikatif, peduli lingkungan, dan peduli sosial.

\section{Implikasi}

\section{Implikasi Teoretis}

Hasil penelitian ini menujukkan bahwa secara teori nilai-nilai karakter dapat diintegrasikan melalui dongeng. Dengan kata lain dongeng sebagai media penyampaian nilai-nilai karakter, relevan dengan pembelajaran pada usia dini. Mengingat bahwa pengetahuan tentang nilainilai karakter adalah bersifat abstrak sedangkan tingkat berpikir usia TK masih dalam tahap kongkret, maka dongeng dengan tokoh-tokoh yang dapat dibayangkan oleh anak menjadi jembatan yang baik agar anak mampu memahami konsep nilai-nilai karakter.

\section{Implikasi Praktis}

Hasil penelitian menunjukkan bahwa banyak nilai-nilai pendidikan karakter yang terintegrasi dalam buku-buku dongeng yang digunakan guru-guru TK. Materi nilai-nilai karakter yang terdapat dalam dongeng muncul dalam diri tokoh-tokoh dongeng dan alur cerita dapat dipahami dengan mudah siswa apabila guru mampu mengaktualisasikan nilai-nilai karakter tersebut pada diri siswa. Kemudian dalam penyusunan buku-buku dongeng berikutnya oleh para penulis dan penerbit buku perlu memperhatikan nilai-nilai karakter agar penanaman karakter melalui dongeng dapat dimulai sejak dini sesuai dengan amanat dalam Undangundang RI No. 20 Tahun 2003.

\section{DAFTAR PUSTAKA}
Abdul Majid, A.A. (2008). Mendidik dengan cerita. Bandung: PT Remaja Rosdakarya

Azzet, A.M. (2011). Urgensi pendidikan karakter di indonesia. Yogyakarta: Ar-Ruzz Media

Bimo. (2011). Mahir mendongeng, membangun dan mendidik karakter anak melalui cerita. Yogyakarta: Pro-U Media 
Bohlin, K. E. (2005). Teaching character education through literature. New York: RoutledgeFalmer

Fitri, A.Z. (2012). Pendidikan karakter berbasis nilai \& etika di sekolah. Yogyakarta: Ar-Ruzz Media

Hetherington, E.M \& Parke, R.D. (1986). Child psychology. Singapore: McGraw-Hill Book Company

Ilyas, Yunahar. (2007). Kuliah akhlak. Yogyakarta: Lembaga Pengkajian dan Pengamalan Islam UMY

Izfanna, Duna \& Hisyam, N. A. (2012). A comprehensive approach in developing akhlaq. Diambil pada tanggal 25 November 2012, dari http://search.proquest.comJamaluddin, Dindin. (2013). Character Education in Islamic Perspective. International Journal of Scientific \& Technology Research volume 2, issue 2, pp.187-189

John, W. S. (2011). Educational psychology. New York: McGraw Hill

Kinayati. (2006). Pesona karya sastra dalam pendidikan dan pengajaran. Jurnal Pendidikan dan Kebudayaan, 063, 737749

Kusmiadi, Ade dkk. (2008). Strategi pembelajaran paud melalui metode dongeng bagi pendidik paud, Jurnal Ilmiah VISI PTK-PNF Vol 3 No. 2, 198-203

Lickona, T. (1992). Educating for character: how our school can teach respect and responsibility. New York: Bantam Books
(2004). Character maters, how to help our children develop good judgement, integrity, and other essential virtues. New York: Touchstoon

Noor, R.M. (2011). Pendidikan karakter berbasis sastra, solusi pendidikan moral yang efektif. Yogyakarta: Ar-ruzz Media

Poerwanti, Endang. (2011). Pengembangan instrument asesmen pendidikan karakter di taman kanak-kanak. Disertasi doktor, tidak diterbitkan, Universitas Negeri Yogyakarta, Yogyakarta.

Siskandar. (2011). The strategy of nation's character education. Journal of Educational Research and Policy. Volume 3 No. 2 i-107

Sit, Masganti. (2009). Mengajarkan kejujuran pada anak usia dini. Jurnal Pendidikan dan Kebudayaan, Vol 15 No 2, 338-351

Sugiono. (2010). Metode penelitian kuantitatif, kualitatif, dan $R \quad \& \quad D$. Bandung: ALFABETA

Suyadi. (2010). Membangun karakter anak dengan metode kisah qur'ani. Jurnal PGMI Al-bidayah, Vol 2 No 2, 289-306

Wibowo, Agus. (2012). Pendidikan karakter usia dini. Yogyakatya: Pustaka Pelajar

Depdiknas .(2003). Undang-undang RI nomor 20, tahun 2003, tentang sistem pendidikan nasional

Kementrian Pendidikan Nasional. (2010). Desain induk pendidikan karakter

Pusat Kurikulum. (2010). Pengembangan dan pendidikan budaya dan karakter bangsa: pedoman sekolah 